\title{
High Temperature Tribological Behavior of Borocarburized Layer on Q235 Steel
}

\author{
Zhengang YANG ${ }^{1}$, Wenping LIANG $^{1 *}$, Yanlin JIA $^{2,3}$, Qiang MIAO ${ }^{1}$, Zheng DING ${ }^{1}$, \\ Haiyang $\mathrm{YU}^{1}$
}

\author{
${ }^{1}$ School of Materials Science and Technology, Nanjing University of Aeronautics and Astronautics, Nanjing 211100, China \\ ${ }^{2}$ College of Materials Science and Engineering, Central South University, Changsha 410083, China \\ ${ }^{3}$ College of Materials Science and Technology, Beijing University of Technology /100 Ping Le Yuan, Chaoyang District, \\ Beijing 100124, China
}

crossref $\mathrm{http}: / / \mathrm{dx} . \mathrm{doi} . o r g / 10.5755 / \mathrm{j} 02 . \mathrm{ms} .24682$

Received 25 November 2019; accepted 22 February 2020

\begin{abstract}
A borocarburized layer was successfully fabricated on the surface of Q235 low-carbon steel via double glow treatment to improve the wear resistance at elevated temperature. The phase composition and microstructure of borocarburized layer were investigated by XRD and SEM. The microhardness of borocarburized layer from the surface to the substrate was studied. The tribological behaviors of borocarburized layer and substrate were investigated under the dry-sliding against $\mathrm{ZrO}_{2}$ ball at three temperatures. The results indicate that the borocarburized layer consists of an outermost boride layer and a transition layer of carburized layer. The boride layer with main phase of $\mathrm{Fe}_{2} \mathrm{~B}$ has a high hardness around $1700 \mathrm{HV}$, and the hardness of transition layer with main phase of $\mathrm{Fe}_{5} \mathrm{C}_{3}$ is around $600 \mathrm{HV}$. The novel gradient structure of an outermost boride layer and inner carburized layer is design in this research decreases the hardness mismatch of coating to prevent the boride layer peeling off. The friction coefficient and specific wear rate of borocarburized layer are much lower than that of substrate at the same temperature. In addition, for the samples after wear test at $20{ }^{\circ} \mathrm{C}$ and $200{ }^{\circ} \mathrm{C}$, it can be concluded that the wear mechanism of borocarburized layer is main abrasive wear while the wear mechanism of substrate is main fatigue wear and sight adhesive wear. As the temperature rises to $500{ }^{\circ} \mathrm{C}$, the tribological behaviour of both borocarburized layer and substrate are main oxidation wear and adhesive wear. The borocarburized layer effectively improves the wear resistance of low carbon steel due to the higher hardness and great thermal stability at high temperature. Keywords: borocarburizing, double glow, surface hardness, tribological behaviour, surface modification.
\end{abstract}

\section{INTRODUCTION}

A majority of low carbon steel components are often used under the severe conditions such as corrosion, oxidation and abrasive wear, which can drastically degrade their mechanical properties [1-3]. Attributing to the inexpensive of low carbon steel, many researchers have not given up on improving its mechanical properties. In recent years, a lot of surface techniques such as induction hardening, surface shot blasting and surface heat treatment are applied to improve the surface performance of steel [4-6]. However, the thermal diffusion technologies [7-10] (nitriding, carburization and nitrocarburizing) are the most favorite option for researchers to treat large numbers of workpieces at a reasonable cost.

Boriding is an effective surface modification technique. The boride layer with great wear resistance of $\mathrm{FeB}$ and $\mathrm{Fe}_{2} \mathrm{~B}$ phase [11], which could substantially improve the wear resistance and corrosion resistance of steels. Nonetheless, traditional boride layer has a serious drawback that is the crack propagation in it due to the difference of thermal expansion coefficient between $\mathrm{FeB}$ and $\mathrm{Fe}_{2} \mathrm{~B}$ phase [12]. Kusmanov et al. [13] pointed out that the boride layer with single-phase $\mathrm{Fe}_{2} \mathrm{~B}$ was better than that with $\mathrm{FeB}$ and $\mathrm{Fe}_{2} \mathrm{~B}$ phase. In addition, boride layer is much harder than steel, which easy to peel off due to the non-uniform distribution of stress in the service of environment [14]. B. Wang et al.
[15] have fabricated the borocarburized layer by plasma electrolytic borocarburizing process which produced the waste and pollution of the electrolyte, the boride layer was undesired due to the $\mathrm{FeB}$ and $\mathrm{Fe}_{2} \mathrm{~B}$ phase. So, it is required to find an effective method to improve the mechanical properties of steels that will be beneficial for the stable operation of the workpiece in a harsh environment.

Recently, double glow plasma surface technology that is a novel method called Xu-Tec by others, deserved great attention. Many practical achievements have confirmed that double glow treatment has unique advantages in preparing coatings $[16,17]$. Using double glow plasma surface technology can save precious metal resources and reduce energy consumption in industrial production. Double glow treatment employs plasma region, which produced by double glow discharges. Beneficial elements are sputtered by argon ions and then go to deposit on substrate surface $[18-20]$. The coatings manufactured by double glow process have gradient structure due to the diffusion of beneficial elements, and the adhesion between coating and substrate is strong because of the metallurgical bonding effects [21-23].

In this paper, the borocarburized layer fabricated on Q235 low-carbon steel via double glow plasma surface technology. The microstructure and phase constituent were determined. Tribological behavior at different temperatures was investigated. Finally, wear mechanism of

\footnotetext{
${ }^{*}$ Corresponding author. Tel.: +86-25-84896089; fax: +86-25-84896089.

E-mail address: wpliang@nuaa.edu.cn (W.P. Liang)
} 
borocarburized layer at different temperatures was discussed.

\section{EXPERIMENT}

The base material was Q235 low-carbon steel (purchased from Beijing Iron and Steel Research Institute of China), and chemical composed (wt.\%) of Q235 steel was $0.35 \mathrm{Mn}, 0.3 \mathrm{Si}, 0.18 \mathrm{C}, \leq 0.04 \mathrm{~S}, \leq 0.04 \mathrm{P}$ and Fe rest. The samples were cut by wire cutting, and the size of each sample was $10 \mathrm{~mm} \times 10 \mathrm{~mm} \times 8 \mathrm{~mm}$. During pretreatment process, the sample was polished by 1200 meshes waterproof abrasive paper, and then cleaned in acetone to dislodge any surface contamination.

The machine of double glow plasma alloying technology consisted of two parts: the cathode and anode (Fig. 1). During the double glow treatment, argon was used as inert gas, which was stimulated as Ar+ because of double glow discharge [24]. The surfaces of target and workpieces were activated due to the bombardment by Ar+ with a certain high kinetic energy [19]. The beneficial elements were sputtered from target to workpiece and diffused into the surface of sample under the high temperature device chamber environment [25]. The borocarburized layer was fabricated by double glow plasma alloying technology in the following steps. Firstly, carburized layer as transition layer was prepared on surface of substrate by pure carbon target, and then boride layer was prepared on the carburized sample by $\mathrm{B}_{4} \mathrm{C}$ target. The detailed experimental parameters are showed in Table 1.

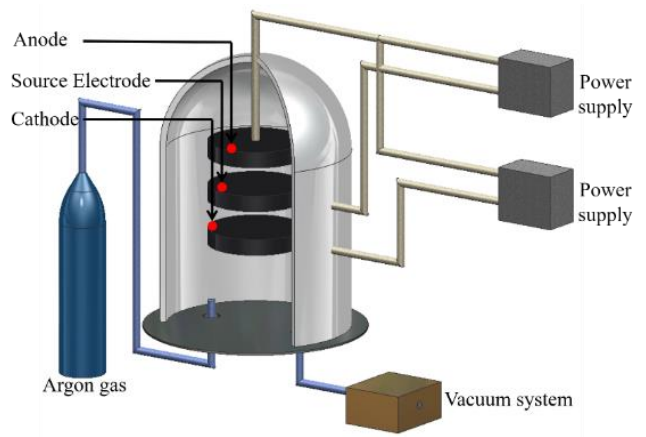

Fig. 1. Sketch of double glow plasma surface alloying machine

Table 1. The experimental parameters of double glow process

\begin{tabular}{|l|c|c|}
\hline \multicolumn{1}{|c|}{ Parameter } & $\begin{array}{c}\text { Values (C } \\
\text { Deposition) }\end{array}$ & $\begin{array}{c}\text { Values (B } \\
\text { Deposition) }\end{array}$ \\
\hline $\begin{array}{l}\text { Voltage of the source electrode, } \\
\text { V }\end{array}$ & 950 & 950 \\
\hline Voltage of the cathode, V & 450 & 550 \\
\hline Working pressure, Pa & 35 & 38 \\
\hline $\begin{array}{l}\text { Distance between the source } \\
\text { electrode and cathode, mm }\end{array}$ & 15 & 10 \\
\hline Treatment time, $\mathrm{h}$ & 3.5 & 4.5 \\
\hline Argon flow rate, sccm & 70 & 50 \\
\hline
\end{tabular}

The Scaning electron microscopy (FEI, Quanta450, USA) was used to determine the surface and the crosssectional microstructure. The phase composition of borocarburized layer was examined by X-ray diffraction (Rigaku, DMAX-RB12KW, Japan) with copper $\mathrm{K} \alpha$ radiation $\left(\lambda=1.5418 \AA, 20^{\circ} \leq 2 \theta \leq 80^{\circ}\right)$. The microhardness of borocarburized layer was examined by a
Vickers Indenter (DianYing, DHV-1000/Z, China) with the applied load of $50 \mathrm{~g}$ and $15 \mathrm{~s}$ dwell time. The ball-on-disk friction and wear tester at high temperature (KaiHua, HT500, China) was used to detect the tribological behaviors of substrate and borocarburized layer in air with relative humidity of $(45 \pm 5) \%$ under dry sliding against $\mathrm{ZrO}_{2}$ ball, the normal load was $730 \mathrm{~g}$ and $560 \mathrm{rpm}$ rotating rate with a turning radius of $2 \mathrm{~mm}$ at $20^{\circ} \mathrm{C}, 200{ }^{\circ} \mathrm{C}$, and $500{ }^{\circ} \mathrm{C}$ respectively. The depth-of-field system (Keyence, VHX1000, Japan) was used to measure the morphology of wear tracks. To evaluate friction and wear performances, the wear volumes and wear rate of the samples were calculated by following equations [26].

$V=\frac{2 \pi \mathrm{hr}}{6 b} \cdot\left(3 h^{2}+4 b^{2}\right)$,

where, $V$ is volume of wear area, $\mathrm{mm}^{3} ; h$ is the depth of wear area, $\mathrm{mm} ; b$ is the width of wear area, $\mathrm{mm} ; r$ is radium of wear area, $\mathrm{mm}$.

$v=\frac{V}{S}$

$K=\frac{V}{S P}$,

where, $v$ is wear rate, $\mathrm{mm}^{3} \mathrm{~m}^{-1} ; S$ represents sliding distance, $\mathrm{m} ; K$ is specific wear rate, $\mathrm{mm}^{3} \mathrm{~N}^{-1} \mathrm{~m}^{-1} ; P$ is the load, $\mathrm{N}$.

\section{RESULTS AND DISCUSSION}

\subsection{Characterization of borocarburized layer}

Fig. 2 shows the surface microstructure of borocarburized layer on low-carbon steel, which is dense and homogeneous. There are a lot of compact submicronsized particles arranged in stacked structure, and this is the typical feature of double glow techniques. The surface roughness of borocarburized layer (around $1.175 \mu \mathrm{m}$ ) is much higher than that of substrate (around $0.217 \mu \mathrm{m}$ ). The results indicated that the beneficial elements were sputtered by active Ar ions, which got a certain high kinetic energy from target to sample due to the difference of the voltage. The beneficial elements with super power unremittingly struck the sample surface caused the increase in the surface roughness.

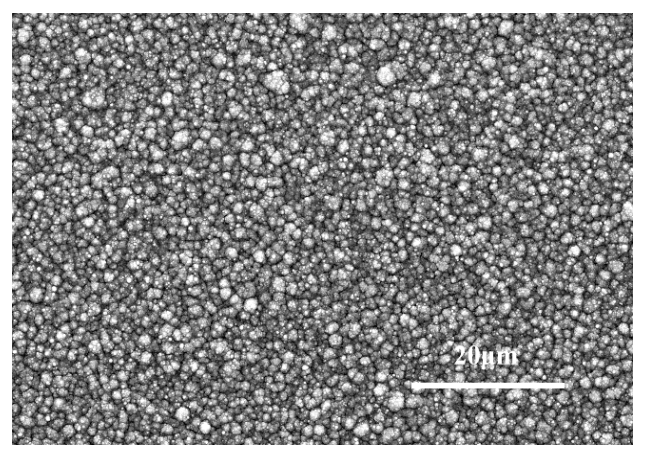

Fig. 2. SEM image of borocarburized layer

The cross-sectional microstructure and EDS results of borocarburized layer are shown in Fig. 3. As shown in figure, the borocarburized layer displays a multilayered structure, and the special structure consists of an outermost boride layer and inner transition carburized layer. The thickness of boride layer and carburized layer are $38 \mu \mathrm{m}$ and 
$75 \mu \mathrm{m}$, respectively. From Fig. 3 b, the EDS results indicated that the distribution of beneficial elements are gradient at the interfaces because of the metallurgical bonding effects, which is a typical feature of double glow plasma alloying technology [19]. Furthermore, the microstructures of boride layer differ from that of the conventional boriding process. The needle-like microstructure cannot be discovered [27]. Salim Sahin et al. [28] indicated that the microstructure of boride layer depends on the temperature, treating time, and the ratio of alloying elements.

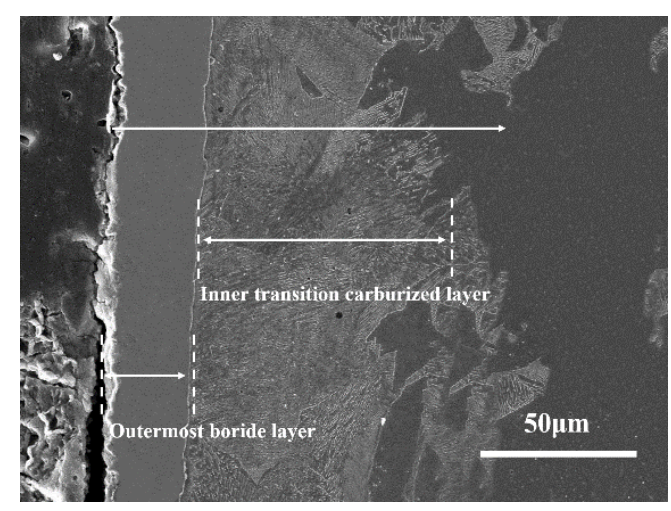

a

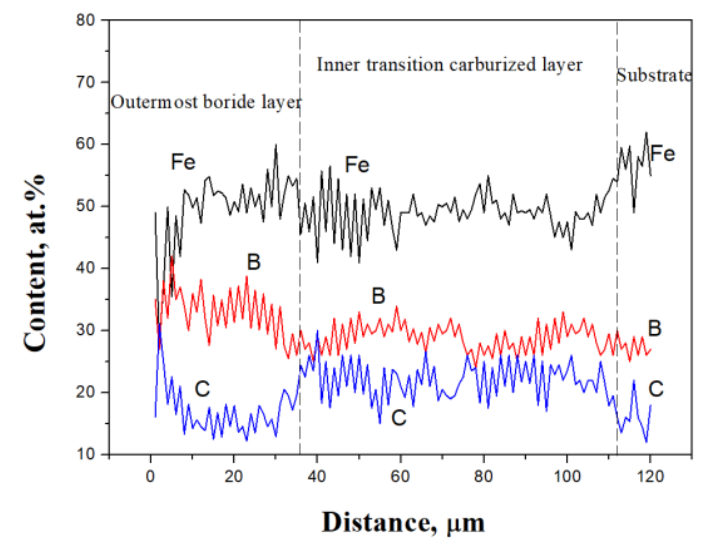

$\mathrm{b}$

Fig. 3. $a-$ cross-section microstructure; b-EDS results of borocarburized layer

The XRD pattern of substrate and borocarburized layer is shown in Fig. 4. After carburizing process, the main phase of sample is $\mathrm{Fe}_{5} \mathrm{C}_{3}$ phase, and $\mathrm{Fe}_{7} \mathrm{C}_{3}$ and $\mathrm{C}_{0.09} \mathrm{Fe}_{1.91}$ are discovered at the same time. The results indicated that carbon atoms diffuse into substrate participated in chemical reaction with iron atoms to form iron-carbon compounds. In addition, only $\mathrm{Fe}_{2} \mathrm{~B}$ phase is detected in Fig. $4 \mathrm{c}$, and the FeB phase in conventional boriding process is absent. The results are consistent with the cross-section microstructure (see Fig. 3 a). And the content of $\mathrm{FeB}$ and $\mathrm{Fe}_{2} \mathrm{~B}$ phase in boride layer principally depends on the ratio of alloying elements and temperature. In general, the XRD technology cannot detect the phase with very lower content (less than $5 \%$ ). Furthermore, the phases of iron-carbon compounds in transition layer cannot be detected in Fig. $4 \mathrm{c}$ because of the high depth from the surface of boride layer to cauburized layer.

Fig. 5 shows the microhardness distributions of borocarburized layer. The results indicated that the microhardness profiles of borocarburized layer from the surface of coating to the substrate is glacis, which could improve the service life of coating in a harsh environment.
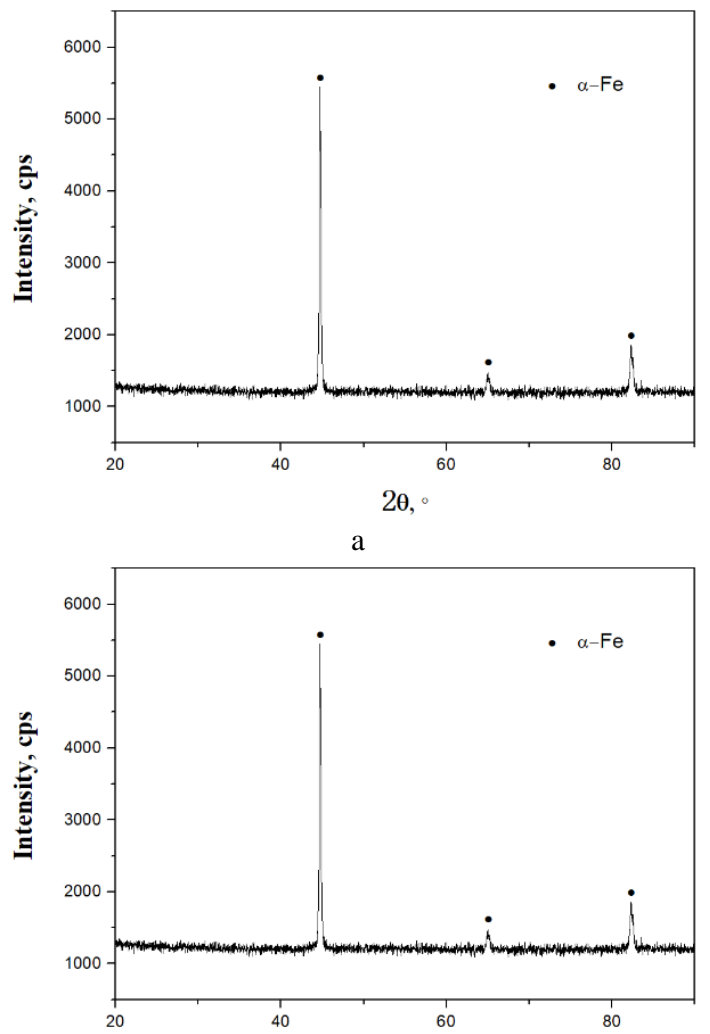

$2 \theta$,

b

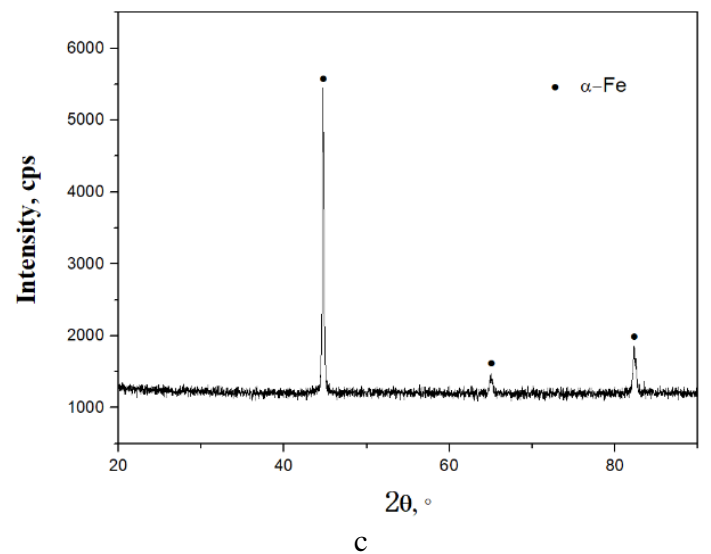

Fig. 4. XRD patterns: a-substrate; $b$-after the carburizing process; $c-$ after boriding process

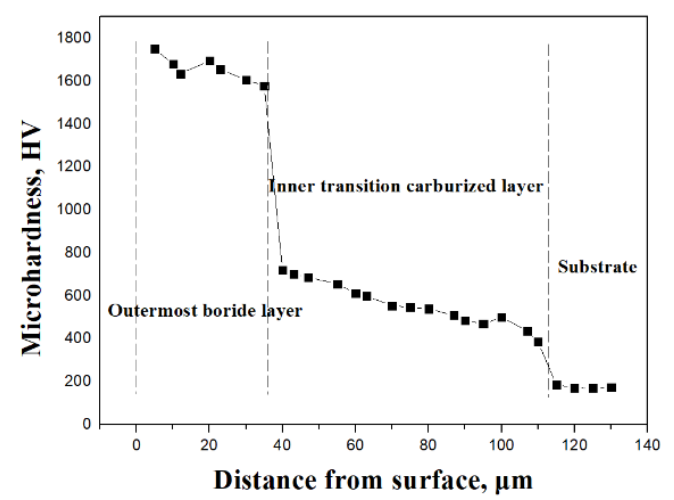

Fig. 5. The microhardness distributions of borocarburized layer 
The effective hard-layer of borocarburized layer is boride layer with the hardness around $1700 \mathrm{HV}$. And the transition layer (carburized layer) has a hardness around $600 \mathrm{HV}$, which delays the hardness gradient between coating and substrate. Above all, the borocarburized layer has an optimized structure, which enhances the hardness of substrate effectively and prevents the outermost layer (boride layer) peeling off.

\subsection{Tribological behavior}

Fig. 6 shows the friction coefficients of substrate and borocarburized layer under dry-sliding against $\mathrm{ZrO}_{2}$ ball with $730 \mathrm{~g}$ load at $20{ }^{\circ} \mathrm{C}, 200{ }^{\circ} \mathrm{C}$, and $500{ }^{\circ} \mathrm{C}$ respectively, and the test was repeated three times for every sample.

The results indicated that the fluctuations of friction coefficients curves of both substrate and borocarburized layer become larger with the increase of temperature. The friction coefficient of substrate at ambient temperature is 0.9 and increases slightly with the rise of environment temperature. However, the friction coefficient of borocarburized layer is only 0.25 at ambient temperature, but it suddenly increases to 0.67 at $200{ }^{\circ} \mathrm{C}$. The friction coefficient of borocarburized layer changes larger with the temperature increase. The friction coefficient of borocarburized layer is much lower than that of substrate at the same conditions, which indicate that the borocarburized layer effectively improves the wear resistance of low carbon steel. Comparing with the friction coefficients of substrate and borocarburized layer, which indicated that the change of that relate to the difference of surface hardness. Krelling A P et al. [29, 30] pointed that the higher hardness of sample led to the lower friction coefficients. During the wear tests, boride layer with $\mathrm{Fe}_{2} \mathrm{~B}$ phase is much harder than substrate, which reduces the real contact areas against the friction pair of $\mathrm{ZrO}_{2}$ ball. With the increase of temperature, the fluctuations of friction coefficients curves of both substrate and borocarburized layer become larger due to the surface roughness of samples. At high temperature, the oxidation of substrate and borocarburized layer occurs easily. The oxide film was broken by friction pair during wear process, and then a lot of abrasive dust was produced immediately, which induced the crash between friction pair and convex parts of substrate surface.

Fig. 7 illustrates the cross-section profiles of wear tracks of Q235 low carbon steel and borocarburized layer at the temperature of $20{ }^{\circ} \mathrm{C}, 200{ }^{\circ} \mathrm{C}$, and $500{ }^{\circ} \mathrm{C}$, respectively. As to substrate, the width and depth of wear tracks increase sharply as the temperature increases because of the oxidation occurs during the wear process. However, the width and depth of borocarburized layer are much smaller than substrate due to the higher hardness of coating at the same conditions.

The results are consistent with the friction coefficients in Fig. 6. In addition, the cross-section profiles of borocarburized layer greatly changes from $200{ }^{\circ} \mathrm{C}$ to $500{ }^{\circ} \mathrm{C}$ due to the oxide film broken and abrasive dust produced during the wear process.

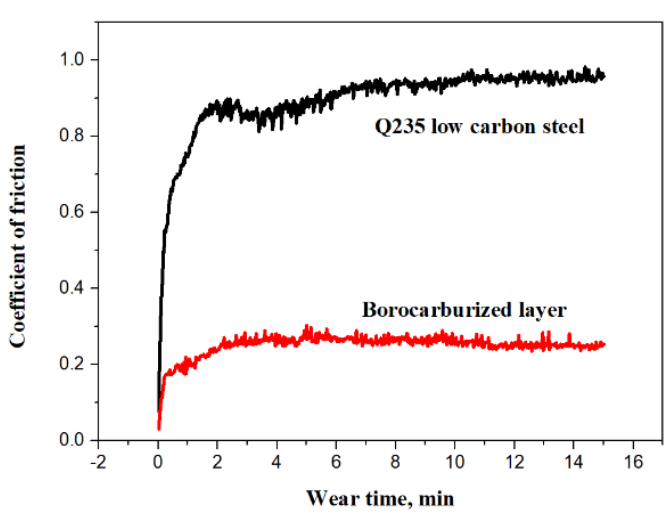

a

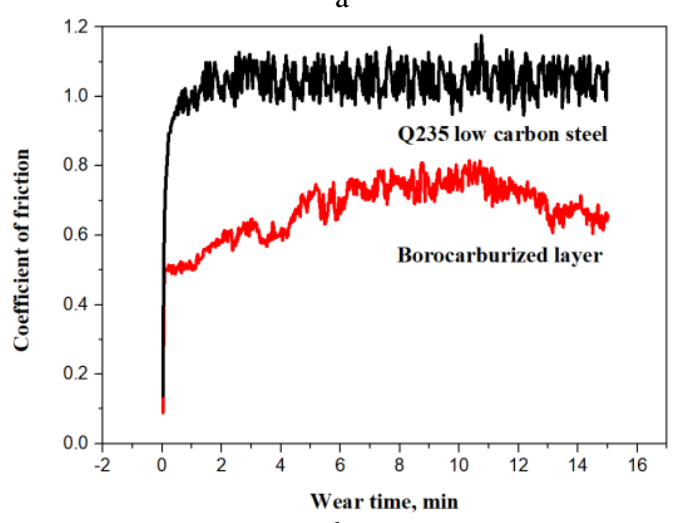

b
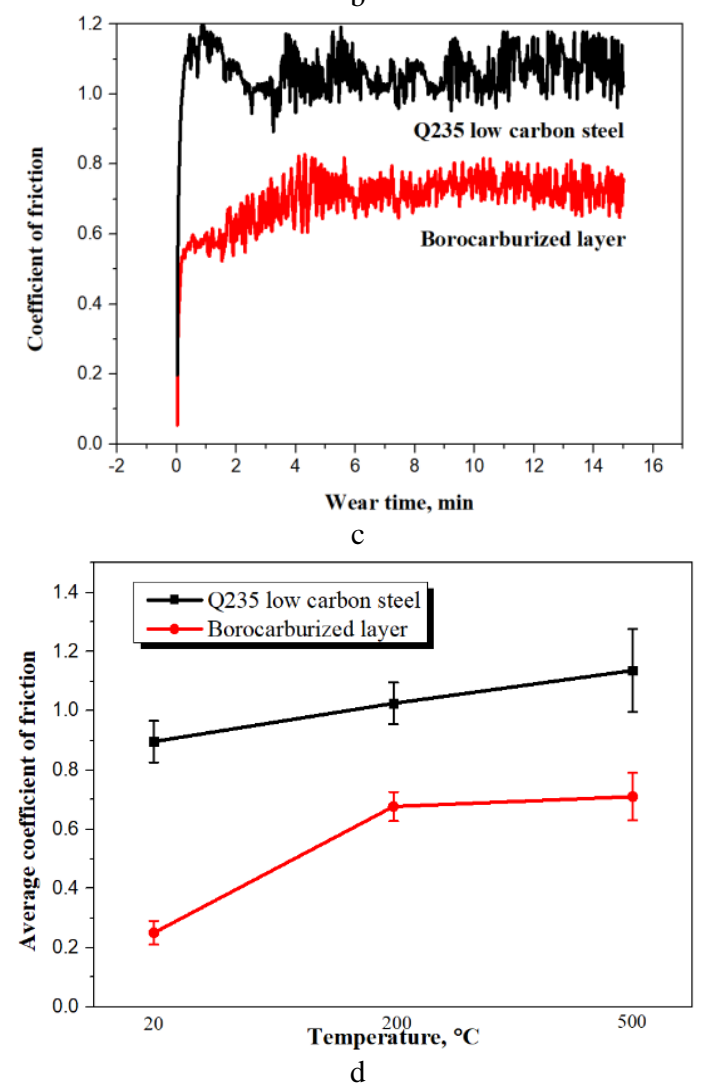

Fig. 6. Friction coefficients of substrate and borocarburized layer under dry-sliding against $\mathrm{ZrO}_{2}$ ball at different temperature: $\mathrm{a}$-ambient temperature; $\mathrm{b}-200{ }^{\circ} \mathrm{C}$; $\mathrm{c}-500{ }^{\circ} \mathrm{C} ; \mathrm{d}$-average coefficient of friction 


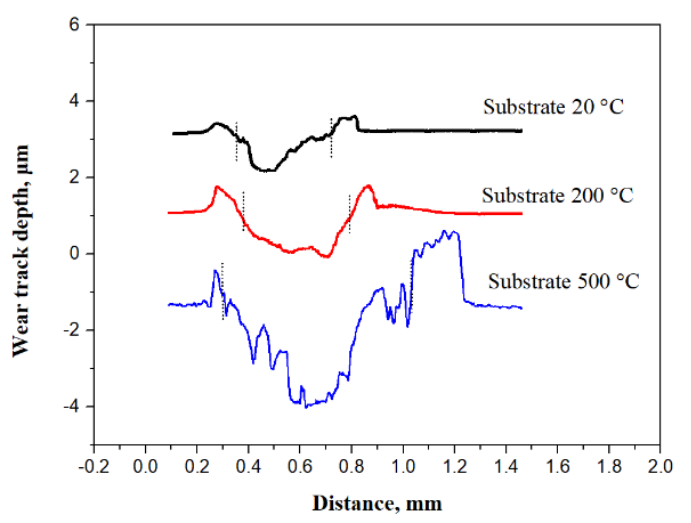

a

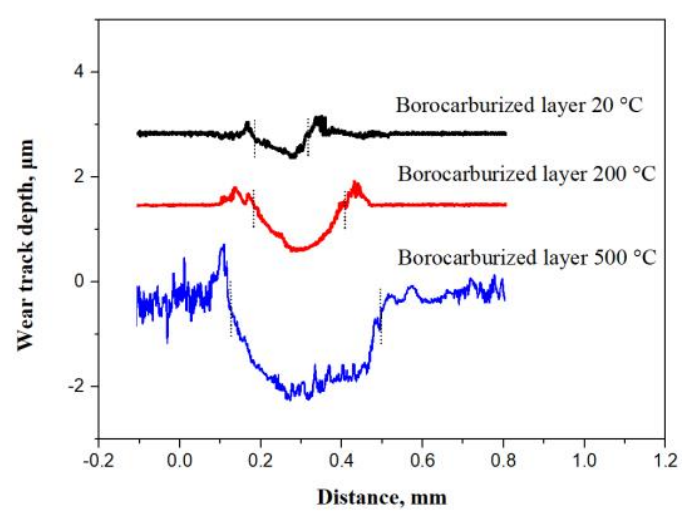

b

Fig. 7. The cross-section profiles of wear tracks: a-substrate; $\mathrm{b}$ - borocarburized layer

Above all, the areas of wear track of borocarburized layer is much smaller than that of substrate at the same condition, which means the borocarburized layer can improve the wear performance at high temperature.

The wear results of 0235 low carbon steel and borocarburized layer were calculated from the cross-section profiles of wear tracks, which were displayed in Table 2.

Table 2. Wear results of substrate and borocarburized layer

\begin{tabular}{|l|c|c|c|c|c|}
\hline \multicolumn{1}{|c|}{ Specimens } & $\begin{array}{c}\text { width } \\
b, \mathrm{~mm}\end{array}$ & $\begin{array}{c}\text { depth } \\
h, \mu \mathrm{m}\end{array}$ & $\begin{array}{c}\text { volume } \\
\text { loss } V, \\
10^{-\mathrm{c}} \mathrm{mm}^{3}\end{array}$ & $\begin{array}{c}\text { wear rate } \\
v, \\
10^{-6} \mathrm{~mm}^{3} \mathrm{~m}^{-1}\end{array}$ & $\begin{array}{c}\text { specific } \\
\text { wear rate } \\
K, \\
10^{-7} \mathrm{~mm}^{3} \mathrm{~N}^{-1} \mathrm{~m} \\
\mathrm{~m}^{\circ}\end{array}$ \\
\hline Substrate $20^{\circ} \mathrm{C}$ & 0.36 & 1.2 & 36.17 & 24.11 & 33.71 \\
\hline Substrate $200^{\circ} \mathrm{C}$ & 0.43 & 1.3 & 46.81 & 31.20 & 43.61 \\
\hline Substrate $500^{\circ} \mathrm{C}$ & 0.76 & 3.1 & 197.28 & 131.52 & 183.84 \\
\hline $\begin{array}{l}\text { Borocarburized } \\
\text { layer } 20^{\circ} \mathrm{C}\end{array}$ & 0.1 & 0.28 & 2.34 & 1.56 & 2.18 \\
\hline $\begin{array}{l}\text { Borocarburized } \\
\text { layer } 200^{\circ} \mathrm{C}\end{array}$ & 0.21 & 0.67 & 11.78 & 7.85 & 10.98 \\
\hline $\begin{array}{l}\text { Borocarburized } \\
\text { layer } 500^{\circ} \mathrm{C}\end{array}$ & 0.32 & 1.2 & 32.15 & 21.44 & 29.96 \\
\hline
\end{tabular}

As for substrate, the wear rate of substrate at $20{ }^{\circ} \mathrm{C}$ is $24.11 \times 10^{-6} \mathrm{~mm}^{3} \mathrm{~m}^{\mathrm{c}}$, which increase rapidly to $131.52 \times 10^{-}$ ${ }^{6} \mathrm{~mm}^{3} \mathrm{~m}^{-1}$ with the temperature rise to $500{ }^{\circ} \mathrm{C}$. And the specific wear rate of it increase rapidly from $33.71 \times 10^{-}$ ${ }^{7} \mathrm{~mm}^{3} \mathrm{~N}^{-1} \mathrm{~m}^{-1}$ to $183.84 \times 10^{-7} \mathrm{~mm}^{3} \mathrm{~N}^{-1} \mathrm{~m}^{-1}$. The results indicate that the substrate is broken badly because of the oxidation at high temperature during the wear process.
However, the wear rate and specific wear rate of borocarburized layer are much lower than that of substrate at the same condition. The wear rate and specific wear rate relate to surface hardness closely, and hardness of the outermost layer (boride layer) is around $1700 \mathrm{HV}$, which is much higher than that of substrate (around $200 \mathrm{HV}$ ). Above all, the borocarburized layer with high hardness improve the wear resistance of low carbon steel at high temperature environment.

The high magnification scanning images of wear tracks shows in Fig. 8 to understand the wear behaviors of Q235 low carbon steel and borocarburized layer under the drysliding against $\mathrm{ZrO}_{2}$ ball with $730 \mathrm{~g}$ load at $20{ }^{\circ} \mathrm{C}, 200{ }^{\circ} \mathrm{C}$, and $500{ }^{\circ} \mathrm{C}$ respectively. Fig. 8 a, c, and e shows the wear surface of substrate at different temperature. The results indicate that a lot of fatigue cracks appear on the wear track at $20{ }^{\circ} \mathrm{C}$, and a large of peeling could be observed at the same time. The wear mechanism of substrate at $20^{\circ} \mathrm{C}$ presents a feature of fatigue wear and slightly adhesive wear. At $200{ }^{\circ} \mathrm{C}$, the adhesion transfer can be observed easily and a lot of abrasive dusts appeared randomly on wear surface, the wear mechanism is mainly adhesive wear and fatigue wear. With the temperature rise to $500{ }^{\circ} \mathrm{C}$, the much severe wear appears on wear surface. Many abrasive dusts are scattered on the wear surface, and some melting materials can be observed on it, which attributes to the local high temperature generated at the interface between $\mathrm{ZrO}_{2}$ ball and sample surface during the wear process. The higher temperature can cause the oxidation, sintering, and the filling of abrasive dusts which is adverse for the wear resistance. Wear mechanism of substrate at $500{ }^{\circ} \mathrm{C}$ is mainly adhesive wear and oxidation wear. Fig. 8 b, d, and f shows wear surface of borocarburized layer at $20{ }^{\circ} \mathrm{C}, 200{ }^{\circ} \mathrm{C}$, and $500{ }^{\circ} \mathrm{C}$, respectively. Comparing with the substrate, the deformation of borocarburized layer is much lower which attribute to the higher hardness of the outermost layer (boride layer) in the coating. At $20^{\circ} \mathrm{C}$, there was no fatigue crack and peeling occurred on the wear track during wear process. When the is increased to $200{ }^{\circ} \mathrm{C}$, slight wear scratches and fine cracks can be observed on wear surface of borocarburized layer, but no extensive spalling or large cracks on it, which indicates that the wear mechanism is slight abrasive wear. At $500{ }^{\circ} \mathrm{C}$, the parallel grooves appear on the wear surface, and relatively smooth wear surface appears evidence of the plastic flow. The results indicate the wear mechanism of borocarburized layer at $500{ }^{\circ} \mathrm{C}$ is main oxidation wear and adhesive wear, but the coating has not been damaged seriously and the wear of it is much weaker than that of substrate due to the great thermal stability of the outermost layer (boride layer) [31]. These suggest that the borocarburized layer effectively improves the wear resistance of low carbon steel at high temperature.

The EDS results of areas I and II in the wear morphology of wear tracks of substrate and borocarburized layer are listed in Table 3. The concentration of $\mathrm{Zr}$ and $\mathrm{O}$ in area I are much higher than that in area II due to the longer contact between friction pairs of $\mathrm{ZrO}_{2}$ and area I during the wear proves. As for both substrate and borocarburized layer, the concentrations of $\mathrm{Zr}$ and $\mathrm{O}$ increase with the temperature rise, which attributes to the oxidation and wear are serious at higher temperature. 
Table 3. The EDS results of areas I and II in the wear morphology of wear tracks of substrate and borocarburized layer

\begin{tabular}{|c|c|c|c|c|c|c|}
\hline \multirow{2}{*}{ Weight percentage, $\%$} & \multicolumn{2}{|c|}{$\mathrm{Fe}$} & \multicolumn{2}{|c|}{$\mathrm{Zr}$} & \multicolumn{2}{|c|}{$\mathrm{O}$} \\
\hline & Area I & Area II & Area I & Area II & Area I & Area II \\
\hline Q235 Substrate $20^{\circ} \mathrm{C}$ & 69.25 & 71.96 & 17.95 & 16.12 & 12.80 & 11.92 \\
\hline Q235 Substrate $200^{\circ} \mathrm{C}$ & 62.17 & 65.82 & 19.26 & 18.73 & 18.57 & 15.45 \\
\hline Q235 Substrate $500^{\circ} \mathrm{C}$ & 56.13 & 58.46 & 24.15 & 21.06 & 19.72 & 20.48 \\
\hline Borocarburized Layer $20^{\circ} \mathrm{C}$ & 77.74 & 81.02 & 10.28 & 9.11 & 11.98 & 9.87 \\
\hline Borocarburized Layer $200{ }^{\circ} \mathrm{C}$ & 67.64 & 70.08 & 13.37 & 12.57 & 18.99 & 17.35 \\
\hline Borocarburized Layer $500{ }^{\circ} \mathrm{C}$ & 65.11 & 66.75 & 15.22 & 14.17 & 19.67 & 19.08 \\
\hline
\end{tabular}

Comparing with the substrate, the concentration of $\mathrm{Zr}$ and $\mathrm{O}$ of borocarburized layer are much lower at the same conditions. The results suggest that the borocarburized layer with high hardness which leads to the abrasive dusts from friction pairs are transferred to the edge of wear tracks [32].

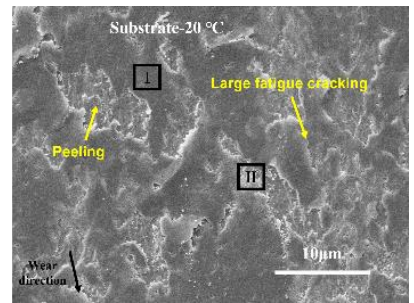

a

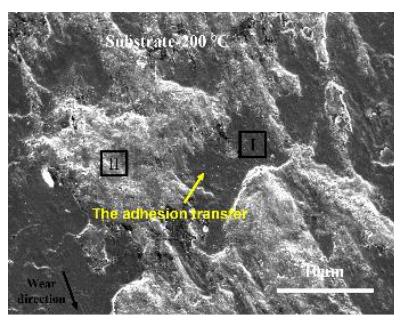

$\mathrm{c}$

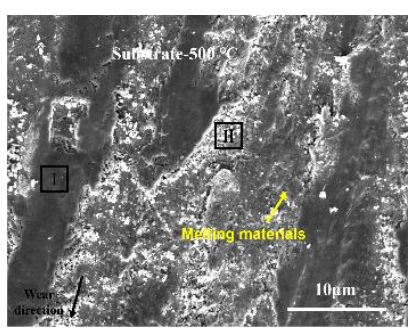

$\mathrm{e}$

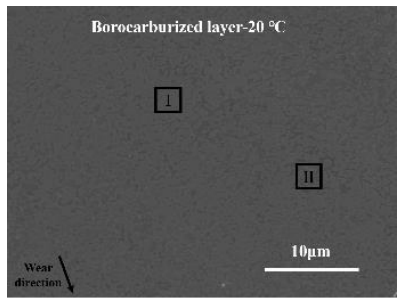

b

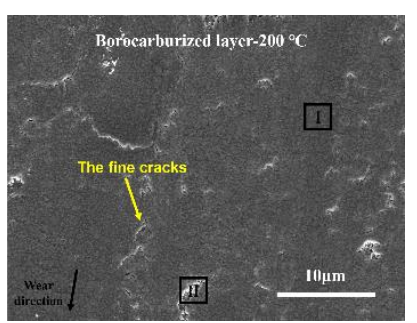

d

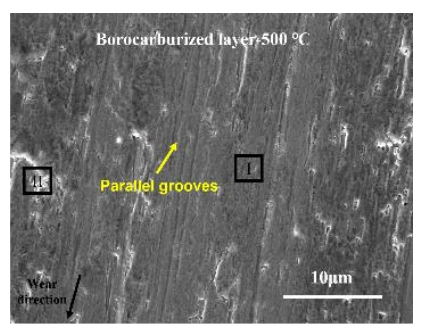

f
Fig. 8. Wear morphology of wear track at ambient temperature, $200{ }^{\circ} \mathrm{C}$, and $500{ }^{\circ} \mathrm{C}$, respectively: a, c and e-substrate; b, $\mathrm{d}$ and $\mathrm{f}$ - borocarburized layer

\section{CONCLUSIONS}

A borocarburized layer with high hardness was fabricated on the surface of Q235 low carbon steel via double glow plasma alloying technology. The protective coating contains an outermost boride layer and an inner carburized layer, which decreased the hardness mismatch to improve the service life of the coating. The borocarburized layer manufactured by double glow plasma alloying treatment has a gradient structure, and the adhesion between coating and substrate is strong because of the metallurgical bonding effects.

The borocarburized layer contains a boride layer with main phase of $\mathrm{Fe}_{2} \mathrm{~B}$ and a carburized layer with main phase of $\mathrm{Fe}_{5} \mathrm{C}_{3}$, which has no obvious defects. The outermost layer (boride layer) has the high hardness around $1700 \mathrm{HV}$, and the hardness of transition layer (carburized layer) is around $600 \mathrm{HV}$.

The friction coefficients and specific wear rates of substrate and borocarburized layer under the dry-sliding against $\mathrm{ZrO}_{2}$ ball increase with rising temperature. But the friction coefficient and specific wear rate of borocarburized layer are much lower than that of substrate at the same temperature. The results suggest that borocarburized layer with high hardness can effectively improve the wear resistance of substrate at high temperature environment.

The wear mechanism of substrate is mainly fatigue wear and slightly adhesive wear at $20{ }^{\circ} \mathrm{C}$. When the wear test performs at $200{ }^{\circ} \mathrm{C}$, the substrate wear mechanism is adhesive wear and fatigue wear. As for borocarburized layer, the main wear mechanism is abrasive wear at $20^{\circ} \mathrm{C}$ and $200{ }^{\circ} \mathrm{C}$. When the temperature increases to $500^{\circ} \mathrm{C}$, the wear mechanism of both substrate and borocarburized layer are main oxidation wear and adhesive wear. The broken of wear tracks of borocarburized layer is lower than that of substrate, which indicates the borocarburized layer effectively improves the wear resistance of low carbon steel at high temperature.

\section{Acknowledgments}

This project was supported by the National Natural Science Foundation of China (No. 51874185) and a project funded by the Priority Academic Program Development of Jiangsu Higher Education Institutions.

\section{REFERENCES}

1. Abdolreza, M., Mehdi, I., Arman, Z. An Experimental Study on Stress Corrosion Behavior of A131/A and A131/AH32 Low Carbon Steels in Simulated Seawater Ocean Engineering 188 2019: pp. 106-204. https://doi.org/10.1016/j.oceaneng.2019.106204

2. Prabhat, K.R., Shekhar, S., Mondal, K. Effects of Grain Size Gradients on the Fretting Wear of a Specially-Processed Low Carbon Steel Against AISI E52100 Bearing Steel Wear 412-413 2018: pp. 1-13.

https://doi.org/10.1016/j.wear.2018.07.014

3. Terasaki, H., Miyahara, Y., Hayashi, K., Moriguchi, K., Morito, S. Digital Identification Scheme for Steel Microstructures in Low-Carbon Steel Materials Characterization 129 2017: pp. 305-312. https://doi.org/10.1016/j.matchar.2017.05.021

4. Chen, J.P., Kang, Y.L., Hao, Y.M., Liu, G.M., Xiong, A.M. Experimental Study on $\mathrm{Ti}+\mathrm{Nb}$ Bearing UltraLow Carbon Bake Hardening Sheet Steel Hot-Rolled in the 
Ferrite Region International Journal of Minerals, Metallurgy and Materials 16 2009: pp. 540-548. https://doi.org/10.1016/S1674-4799(09)60093-5

5. Okan, U., Remzi, V. Almen Intensity Effect on Microstructure and Mechanical Properties of Low Carbon Steel Subjected to Severe Shot Peening Applied Surface Science 290 2014: pp. 40-47.

https://doi.org/10.1016/j.apsusc.2013.10.184

6. Lan, L.Y., Zhang, Y.T., Kong, X.W. Dynamic Fracture Behavior of Low Carbon Bainitic Steel after Different Welding Thermal Cycles Engineering Fracture Mechanics 220 2019: pp. $106-653$.

https://doi.org/10.1016/j.engfracmech.2019.106653

7. Wang, J., Li, Z., Wang, D., Qiu, S., Ernst, F. Thermal Stability of Low-Temperature-Carburized Austenitic Stainless Steel Acta Materialia 128 2017: pp. 235-240. https://doi.org/10.1016/j.actamat.2017.02.018

8. Doan, T.V., Kusmič, D., Pospíchal, M., Dobrocký, D. Improvement of Wear Resistance for C45 Steel Using Plasma Nitriding, Nitrocarburizing and Nitriding/Manganese Phosphating Duplex Treatment Materials Science and Engineering 179 2017: pp. 012017. https://doi.org/10.1088/1757-899X/179/1/012017

9. Wang, Y., Yang, Y., Yang, H., Zhang, M., Qiao, J. Effect of Nitriding on the Tribological Properties of Al1.3CoCuFeNi2 High-Entropy Alloy Journal of Alloys and Compounds 725 2017: pp. 365-372. https://doi.org/10.1016/j.jallcom.2017.07.132

10. Dalke, A., Burlacov, I., Spies, H.J., Biermann, H. Use of a Solid Carbon Precursor for DC Plasma Nitrocarburizing of AISI 4140 Steel Vacuum 149 2018: pp. 146-149. https://doi.org/10.1016/j.vacuum.2017.12.033

11. Kulka, M., Pertek, A., Klimek, L. The Influence of Carbon Content in the Borided Fe-Alloys on the Microstructure of Iron Borides Materials Characterization 56 2006: pp. $232-240$.

https://doi.org/10.1016/j.matchar.2005.11.013

12. Kartal, G., Eryilmaz, O.L., Krumdick, G. Erdemir, A., Timur, S. Kinetics of Electrochemical Boriding of Low Carbon Steel Applied Surface Science 257 2011: pp. 6928-6934.

13. Kusmanov, S.A., Tambovskiy, I.V., Sevostyanova, V.S., Savushkina, S.V., Belkin, P.N. Anode Plasma Electrolytic Boriding of Medium Carbon Steel Surface and Coatings Technology 291 2016: pp. 334-341. https://doi.org/10.1016/j.apsusc.2011.03.034

14. Kulka, M., Mikolajczak, D., Makuch, N., Dziarski, P., Miklaszewski, A. Wear Resistance Improvement of Austenitic 3161 Steel by Laser Alloying with Boron Surface and Coatings Technology 291 2016: pp. $292-313$.

https://doi.org/10.1016/j.surfcoat.2016.02.058

15. Wang, B., Xue, W., Jie, W.U., Jin, X., Hua, M., Zhenglong, W.U. Characterization of Surface Hardened Layers on q235 Low-carbon Steel Treated by Plasma Electrolytic Borocarburizing Journal of Alloys and Compounds 578 2013: pp. 162-169. https://doi.org/10.1016/j.jallcom.2013.04.153

16. Lin, N.M., Zhang, L.X., Zou, J.J., Liu, Q., Yuan, S., Zhao, L.L., Yu, Y., Liu, Z.Q., Zeng, Q.F., Liu, X.P., Wang, Z.H., Tang, B., Wu, Y.C. A Combined Surface Treatment of Surface Texturing-Double Glow Plasma Surface Titanizing on AISI 316 Stainless Steel to Combat Surface Damage: Comparative Appraisals of Corrosion
Resistance and Wear Resistance Applied Surface Science 493 2019: pp. 747-765.

https://doi.org/10.1016/j.apsusc.2019.06.028

17. Cheng, F.P., Sun, J.C. Fabrication of A Double-layered CoMn-O Spinel Coating on Stainless Steel via the Double Glow Plasma Alloying Process and Preoxidation Treatment as SOFC Interconnect International Journal of Hydrogen Energy 44 2019: pp. 18415-18424. https://doi.org/10.1016/j.ijhydene.2019.05.060

18. Wei, D.B., Zhang, P.Z., Yao, Z.J., Wei, X.F., Zhou, J.T., Chen, X.H. Preparation and High-Temperature Oxidation Behavior of Plasma Cr-Ni Alloying on Ti6al4v Alloy Based on Double Glow Plasma Surface Metallurgy Technology Applied Surface Science Part A 388 2015: pp. 571-578. https://doi.org/10.1016/j.apsusc.2015.10.064

19. Cui, S., Miao, Q., Liang, W., Li, B. Oxidation Behavior of NiCoCrAlY Coatings Deposited by Double-Glow Plasma Alloying Applied Surface Science 428 2018: pp. $781-787$ https://doi.org/10.1016/j.apsusc.2017.09.215

20. Chen, X., Zhang, P., Wei, D., Ding, F., Li, F., Wei, X. Preparation and Characterization of $\mathrm{Cr} / \mathrm{CrC}$ Multilayer on $\gamma$ TiAl Alloy by the Double Glow Plasma Surface Alloying Technology Materials Letters 215 2018: pp. 292-295. https://doi.org/10.1016/j.matlet.2017.12.104

21. Yang, Z., Liang, W., Miao, Q., Chen, B., Ding, Z., Nipon, R. Oxidation Behavior of $\mathrm{Al} / \mathrm{Cr}$ Coating on Ti2AlNb Alloy at $900{ }^{\circ} \mathrm{C} \quad$ Materials Research Express 5 2018: pp. 046408 . http://doi.org/10.1088/2053-1591/aabab1

22. Guo, L., Qin, L., Kong, F., Yi, H., Tang, B. Improving Tribological Properties of Ti-5Zr-3Sn-5Mo-15Nb Alloy by Double Glow Plasma Surface Alloying Applied Surface Science 388 2016: pp. 203-211.

https://doi.org/10.1016/j.apsusc.2016.01.201

23. Chen, Z., Wu, W., Cong, X. Oxidation Resistance Coatings of $\mathrm{Ir}-\mathrm{Zr}$ and Ir by Double Glow Plasma Journal of Materials Science \& Technology 30 2014: pp. 268-274. https://doi.org/10.1016/j.jmst.2013.06.002

24. Zheng, Y., Zhong, J., Lv, X.P., Zhao, Y.J., Zhou, W., Zhang, Y.X. Microstructure and Performance of Functionally Graded Ti(C,N)-Based Cermets Prepared by Double-Glow Plasma Carburization International Journal of Refractory Metals \& Hard Materials 44 2014: pp. $109-112$. https://doi.org/10.1016/j.ijrmhm.2014.01.002

25. Luo, X.X., Yao, Z.J., Zhang, P.Z., Chen, Y., Yang, H.Q., Wu, X.F., Zhang, Z.L., Lin, Y.H., Xu, S.J. Tribological Behaviors of $\mathrm{Fe}-\mathrm{Al}-\mathrm{Cr}-\mathrm{Nb}$ Alloyed Layer Deposited on 45 Steel via Double Glow Plasma Surface Metallurgy Technique The Transactions of Nonferrous Metals Society of China 25 2015: pp. 3694-3699. https://doi.org/10.1016/S1003-6326(15)64010-9

26. Lu, H.F., Miao, Q., Liang, W.P., Wang, F., Ding, Z., Xia, J.J. High-Temperature Tribological Behaviors of a CrSi Co-Alloyed Layer on TA15 Alloy Chinese Journal of Aeronautics 30 2017: pp. 846-855. https://doi.org/10.1016/j.cja.2016.10.020

27. Kartal, G., Timur, S., $\quad$ Sista, V., $\quad$ Eryilmaz, O.L., Erdemir, A. The Growth of Single Fe2B Phase on Low Carbon Steel via Phase Homogenization in Electrochemical Boriding (PHEB) Surface and Coatings Technology 206 2011: pp. 2005-2011. https://doi.org/10.1016/j.surfcoat.2011.08.049 
28. Salim, S., Cevdet, M. Investigation of the Effect of Boronizing on Cast Irons Materials Research Bulletin 37 2002 pp. $971-979$.

https://doi.org/10.1016/S0025-5408(02)00697-9

29. Krelling, A.P., Da-Costa, C.E., Milan, J.C.G., Almeida, E.A.S. Micro-Abrasive Wear Mechanisms of Borided AISI 1020 Steel Tribology International 111 2017: pp. $234-242$.

https://doi.org/10.1016/j.triboint.2017.03.017

30. Campos-Silva, I., Flores-Jiménez, M.,

BravoBárcenas, D., Balmori-Ramírez, H., Andraca-Adame, J., Martínez-Trinidad, J., Meda-Campañaa, J.A. Evolution of Boride Layers During a Diffusion Annealing Process Surface and Coatings Technology 309 2017: pp. $155-163$.

https://doi.org/10.1016/j.surfcoat.2016.11.054
31. Arun, K.R.,

Raju, S.,

Jeya-Ganesh, B., Panneerselvam, G., Vijayalakshmi, M., Jayakumar, T., Baldev, R. Investigation of High Temperature Phase Stability, Thermal Properties and Evaluation of Metallurgical Compatibility with 304L Stainless Steel, of Indigenously Developed Ferroboron Alternate Shielding Material for Fast Reactor Applications Nuclear Engineering and Design 241 2011 pp. 2787-2801. https://doi.org/10.1016/j.nucengdes.2011.05.039

32. Xiao, P., Gao, Y.M., Xu, F.X., Yang, C.C., Li, Y.F., Liu, Z.W., Zheng, Q.L. Tribological Behavior of In-Situ nanosized TiB2 Particles Reinforced AZ91 Matrix Composite Tribology International 2018: pp. $130-139$.

https://doi.org/10.1016/j.triboint.2018.07.003

(C) Yang et al. 2021 Open Access This article is distributed under the terms of the Creative Commons Attribution 4.0 International License (http://creativecommons.org/licenses/by/4.0/), which permits unrestricted use, distribution, and reproduction in any medium, provided you give appropriate credit to the original author(s) and the source, provide a link to the Creative Commons license, and indicate if changes were made. 